\title{
Issues and Challenges in Implementing China's Green Public Procurement Program
}

\author{
Yuhua Qiao', Conghu Wang ${ }^{2}$ \\ ${ }^{1}$ Department of Political Science, Missouri State University, Springfield, USA; ${ }^{2}$ School of Public Administration, Renmin University \\ of China. \\ Email: YuhuaQiao@MissouriState.edu
}

Received July 23 ${ }^{\text {rd }}, 2011$; revised August 28 ${ }^{\text {th }}$, 2011; accepted September $29^{\text {th }}, 2011$.

\begin{abstract}
Sustainable development and environmental protection are the themes of the day. One popular policy tool that government uses to promote sustainable development and to protect the environment is green public procurement. Chinese government established its public procurement system in the late 1990s. It has moved to implement green procurement since 2004. In this paper, the authors will first trace the development of Chinese green public procurement program. The authors will then examine the issues involved in its implementation and make suggestions as to how to make green public procurement program more effective. This is one of the first papers examining China's green public procurement program.
\end{abstract}

Keywords: China Green Procurement Laws, China Green Procurement Program Implementation Issues

\section{Introduction}

Public procurement has always served as a policy tool [1]. Today, it has been called upon to accomplish another important mission: to promote sustainable economic development and to protect environment. Sustainable procurement is closely related to sustainable development. It advocates consumption behaviors that have no or little environmental impact and that are economically sound in the longer run. Green procurement, also known as environmental procurement, eco-procurement or green government procurement, is not a synonym to sustainable procurement. Rather it is a sub-concept referring to the environmental dimension only [2]. In this paper, the emphasis is on China's green procurement.

As the largest developing country with the fastest growing economy, China is facing serious environmental pollution and the danger of depleting some of its natural resources. Though establishing its public procurement system just in 1990s, Chinese government has realized the importance and necessity of using public procurement to protect its environment and to promote the sustainable development. With its huge expenditure, Chinese government's use of green procurement will have significant leverage on adjusting the environment, resource and economic development.

This is one of the first studies that examines the Chi- nese government green procurement program. In this paper, the authors will first review literature about green public procurement and its implementation in the world, particularly in the Europe Union, and about the development of Chinese green public procurement. The authors will then examine the issues involved in its implementation and make suggestions as to how to make green public procurement program more effective.

\section{Literature Review}

As China has just established its green public procurement program, little writing has been generated. In this section, the authors will review literature about green public procurement development and implementation in the developed world, particularly European Union so as to provide insightful understanding about the overall trend and the implementation.

According to McCrudden [1], government has always used its purchasing power to achieve policy goals, ranging from the early protecting national industries against foreign competition to the modern promotion of social equality. Using purchasing power for environmental protection and sustainable development is relatively recent. According to a 1997 Organizations for Economic Cooperation and Development (OECD) report, the Danish strategy to promote sustainable procurement policy in 
1991 marked the beginning of such a policy. Then by the late 1990s, green public procurement became common at national, regional, and international levels. Such a rapid development was the response to the serious environmental deterioration and the excessive use of natural resources and was also pushed by various international and regional organizations, including the United Unions, OECD, European Commission, and the World Trade Organizations [3].

The United Nations held several conferences in the 1990s to recognize the importance of environmental protection and human rights. The 1992 UN Conference on Environment and Development, also known as Earth Summit, held in Rio de Janerio, Brazil, "was a turning point for environmental issues” [1]. Over 178 nations adopted the Rio Declaration on Environment and Development. A plan of action, referred to as Agenda 21, calls for governments to adopt action-oriented policies and goals to encourage governments to use their purchasing power to improve their own environmental performance. In 1997, UN established a Commission on Sustainable Development to monitor and report on the implementation of the agreement at the local, national, regional, and international level [1,3]. In the World Summit on Sustainable Development held in 2002, UN passed the Plan of Implementation encouraging government to use public procurement policies to promote sustainable development and environment protection [4]. UN also uses its procurement power to influence the actions in various areas, including environment protection [3].

The 1992 UN Earth Summit pushed the green procurement initiatives in various ways. In 1995, G7 Environmental ministers agreed to "green" their own government. In 1996, an OECD Council recommended members adopt implementation policies to purchase environmental friendly products and services. In the same year, "Green Purchasing Network" was established in Japan and the International Council for Local Environmental Initiatives (ICLEI) launched European Eco-Procurement Initiative. In 1997, the United States federal government adopted green procurement policy through an executive order. The coming years saw hundreds of local leaders from Europe and other areas expressing their commitment to green public procurement in "Hanover Call" and "Lyon Declaration." In 2001, an Interagency Sustainable Procurement Group was established under the sponsorship of multilateral development banks, UN organizations, and several NGOs [1].

Within the European Union, European Commission sees environment protection as its central policy goals. It lays out the major legal framework in several EU directives and regulations during 2004 and 2006 [1]. EU requires that environment protection be integrated to other policies and activities. The Commission has urged the member states to make better use of government procurement to green the market and to promote sustainable objective. One of the major strategies to promote green procurement is the use of eco-labels system that certifies the products meeting the environmental protection criteria. The system was first established at the Community level in 1992 and further developed and proliferated at other levels in the coming years. Another strategy is the environment impact assessment required for all government contract works before government makes any decision [1]. The Europe Union also recommends by 2006 the member states design publicly available action plans to green public procurement. The plans should assess the present situation and set up ambitious target for the situation in three years time. The action plans should also state clearly what measures will be taken to achieve the target [5].

The World Trade Organization (WTO) and Government Purchasing Agreement, though not expressively requiring green procurement, are interpreted as supportive for such a use. In general, the WTO considers that the open, non-discriminatory, and equitable multilateral trading system should not and needs not be contradictory to actions for environment protection and sustainable development. In Government Procurement Agreement - in the similar frameworks as WTO but with a narrower group of signatories, there is no specific mentioning of environmental protection. However, the Sixth Recital of the Preamble to the WTO agreement recognizes the need to act in accordance with the principles of sustainable development and to protect and preserve the environment. Therefore, it is generally held that GPA allows contracting entities to consider environmental impact when defining technical specifications (including process and production methods) and selection and award criteria, given that these actions are non-discriminatory, objective and verifiable $[3,4]$.

While the OECD countries are leading users of green public procurement, some developing countries are also starting to adopt policies to implement it. Various studies have been conducted concerning the GPP implementation in the developed world, particular EU members. According to Classon and Waara [6], EU takes a process view in its implementation. That is government takes into consideration the environmental impact in each of its procurement process-in technical specification, in technical specifications, in selection criteria, in the awards of contracts, and in contract performance clauses. Government usually adopt policies considering the life cycle cost of a product, giving price preferences to green products (e.g., recycled products, energy-using devices, organic products, alternative fuels, clean electricity) and 
encouraging less-polluting manufacturing technologies, setting aside for greener products and providing information provision and training [7].

Though the calling for GPP is strong, the commitment differs a great deal from nation to nation. According to a 2003 study sponsored by ICLEI, Denmark and Sweden demonstrate the highest level of commitment in European Union [8]. Denmark and Sweden earned the top rating again in another study that examined only the four North European countries-Denmark, Finland, Norway, and Sweden [9]. ICLEI project also demonstrated GPP can result in great savings. For instance, if all the public authorities purchase green electricity, this would reduce the gas emissions by $18 \%$ of the EU's Kyoto commitment. Similar savings will occur with many other green products $[4,8]$.

The report-Green Public Procurement in Europe 2006 - sponsored by five environmental organizations, intended to reveal the state of green public procurement in $25 \mathrm{EU}$ member states. The study identified "Green 7" and "Other 18". The "Green 7" are Austria, Denmark, Finland, Germany, Netherlands, Sweden, and U.K. The remaining EU members are "other 18". The data for this study are from two sources. One was from the 865 responses to 8787 questionnaires, and the other was from a survey of actual 1000 tender documents. The study also reveal the inconsistent findings from different data sources. While $67 \%$ of the questionnaire respondents reported the use environmental criteria in procurement, the tender documents reveal only $36 \%$ of purchases use some environment criteria. This may indicates the public personnel exaggerate their actual implementation of PGG [10,12]. Parikka-Alhola, NIssinen and Ekroos [5] examined the use of GPP in Finland, Sweden, and Demark through the tenders calls used in 2005. They found almost one third of the tender calls contain environmental criteria, including environmental policy and environmental management system, requiring the fulfillment of eco-label criteria, chemical content, recycling or reuse system, packaging material and noise. They also found out that public authorities give the average weight of 3.3\% to environmental criteria [5].

In 2007, Stephen Brammer and Helen Walker conducted the "first systematic and comprehensive" study about sustainable procurement practice among 25 countries. Questionnaires were sent to 1500 public procurement personnel asking about their use of sustainable procurement with the maximum level of five. Only 283 responded, and the average rating is 2.82 . It is unclear what this score means.

Many studies are conducted at the national level. A 2004 survey was conducted concerning green procurement in Sweden with a sample of 558 public authorities.
The results show that $15 \%$ of the 400 respondents stated that they always used environmental requirement, $46 \%$ usually did, $27 \%$ sometimes did, and $10 \%$ seldom or never do [6]. Prenen reviewed five studies conducted in Dutch regarding the use of sustainable procurement in 2004, 2006, 2007, and 2008 through questionnaires sent to public procurement professionals. The percentage of the respondents who confirm their use of sustainable procurement varies: 23\% in 2004 survey, 32\% in 2006 survey, $48 \%$ in 2007 , and $23 \%$ in 2008 . Prenen examined the same issue by examining the actual tender documents and found that only $16 \%$ of the contracts he examined contain "relatively many indications" or "all indications" (558) that indicate that sustainability was a major requirement in public procurement [12].

These studies also reveal various limitations and obstacles in implementing GPP and SPP. Guntner indentified several "hurdles," including lack of support by guidelines, a lack of information about the products, their functionalities and the prices, requirement of more work, and uncertainty of legislation [13]. The 2003 ICLEI survey found that lack of money was the major obstacle for countries with high-level commitment and the lack of environmental know-how for those with low-level commitment. [8]. In the 2004 Sweden survey, almost half of respondents stated the major obstacle lie in the lack of the information as to how to formulate environmental requirements. Approximately a third identified higher costs, lack of interest, and legal concerns as obstacles [6]. The Green Public Procurement in Europe 2005 and Green Public procurement in Europe 2006 report that the perception of high costs was identified as the top obstacle followed by the lack of knowledge, lack of management support, lack of practical tools and information, and lack of training $[5,10]$.

Carlsson and Waara study the Swedish local government procurement agencies. They also identified several limitations and their impact on the implementation of GPP. The first one is the lack of administrative resources (including environmental know-how). As a result, public procurement officers tend to use easy-to-evaluated environmental criteria such as whether the bidder has a corporate environmental policy or not. The second one is lean budget and the high cost of green products and services. Another one is the concern for legal challenge by unsuccessful bidders and the public procurement officers' consequent refraining from using environmentally related award criteria [6].

While this increasing amount of research is valuable for us to understand the implementation of GPP in the developed world, they have several weaknesses. First, many studies suffer low response rates, and non-responses are not examined. Second, the responses may be 
biased toward the answers that are political and social popular. Third, nearly all of the research conducted so far focuses on GPP in the developed world. This is understandable since they are the leading users of GPP. However, many developing countries such as China, have come to use GPP and SPP as a tool to protect the environment and resource. It is important to examine how they set up their legal frameworks and what obstacles, similar or unique, they are facing in their implementation, and what lessens and advice the developed countries may offer them developing countries. In the following sections, the authors will review the development of China's GPP development by examining the major relevant laws and regulations and examine the issues that China faces in its implementation.

\section{China Green Public Procurement Program}

China has a relatively short history of public procurement system. Its public procurement system only started in the 1990s. Ju, Zhan, Ren, and Yang divide the development into three stages. Its embryonic stage covers the period of 1993-2003 [14]. In 1993, the first procurement legislation - Bidding Law and Government Procurement Law- was drafted. Pilot programs of using tendering and bidding were conducted in Shanghai in 1996 and Shenzhen in 1997. This led to a nation-wide public procurement reform and system construction [14]. The most important achievements in this stage are the establishment of bidding system for public procurement, the creation of local government procurement organizations, and enactments of Government Procurement Law and the Clean Production Promotion Law of the People's Republic of China in 2002 [14]. The concept of green procurement also emerges in this stage. As will be explained later, both Government Procurement Law and the Clean Production Law of the People's Republic of China are the center pieces in designing green procurement.

The second stage (2004-2007), saw the enactment of a few legislations promoting green public procurement to respond to the emergence of the scientific development concept that emphasizes "people-oriented" and "a comprehensive, coordinated and sustainable development" [14]. The series of laws include Notification on Resource-saving Activities by the State Council Office, Opinions of Implementing Government Procurement of Energy-saving Products and Decision on Carrying Out Scientist Development Concept by Strengthening Environment Protection of 2005, and the Opinions on Implementation of Government Procurement for Environmental Labeling Products of 2006 [14].

The third stage, the comprehensive development stage (2007-the present) is marked with China's effort to meet the requirement of the World Trade Organization (WTO)'s Agreement on Government Procurement. In this stage China passed various laws to promote further green public procurement, including National Environment Protection in $11^{\text {th }}$ Five Year Planning, Energy Saving and Expulsion Reducing Scheme and Energy Saving Law, Circular Economy Promotion Law and Public Organs' Energy Saving Regulations (2008) and the State Council Office Gave Notice on Forcefully Establishing Government Procurement System for Energy Saving Products and Notification on Public Purchasing List of Adjusting Environmental Labeling Products [14].

\subsection{The Legal Sources of China Green Procurement}

Government green procurement in China is set in a series of laws as highlighted above. Three of the most important ones that define the policy goals and directions will be furthered examined here. The first one is the Clean Production Promotion Law of the People's Republic of China of 2002 [15]. The $16^{\text {th }}$ Article stipulates that governments at all levels, in their procurements, should give priorities to the products that are environmental friendly and resource-using conservative. This includes those products that can conserve energy and water and that are recyclable. The provision also stipulates that all levels of government should use advocacy and education to encourage the public to purchase and to use environmental friendly and resource conservative products. Indeed, the first half of the $16^{\text {th }}$ provision sets government green procurement policy. The second half sets the policy for the government to promote green procurement among the public.

The second important piece of legislation is the Government Procurement Law which began its implementation in Jan. 2003. The ninth article requires government procurement to be used for environment protection. Government procurement should be used to promote environment friendly productions and to acquire the goods that meet the environment protection standards. In other words, government cannot procure the products whose producing environment does not meet the environment standard and cannot procure the products that do not meet the environment protection standards [16]. The $22^{\text {nd }}$ Article states that suppliers who break the rule three years should be excluded from the public procurement supplier list.

The third piece is The Circular Economy Promotion Law of the People's Republic of China which began its implementation in Jan. 2009. Article 1 Section 8 requires that governments that are higher than county government should establish responsibility system to promote circular economy and should use policy design, fiscal power, 
investment opportunities, and government procurement power to promote circular economy [17].

\subsection{Specific Policy Measures for Government Green Procurement}

Green purchasing list is an important method in China's green public procurement. The green purchasing list consists of two parts: the environment labeling product public purchasing list and the energy-saving product public purchasing list [14].

\subsection{Energy-Saving List}

The energy-saving list covers both energy-saving products (e.g. air conditioners, refrigerators, florescent lamps, electric water heaters, printers, etc) and water saving products (e.g., faucets, toilet flush valves, tank fitting, etc.). In December 2004, the Finance Ministry and the National Development and Reform Committee issued Implementation Guidelines for Government Procurement of Energy-saving Products (or The Guidelines). The Guidelines make it clear that procurement of energysaving products is a significant step in reducing government energy costs, promoting enterprise development of new energy efficient technology, expanding energy efficiency market, and raising the public consciousness about resource, saving energy, protect the environment, promote the sustainable development [18].

At the same time, the Finance Ministry and the National Development and Reform Committee defined the government procurement scope with the certified energyefficient products and issued government energy-efficient procurement product list. If the products provide the same service and technology, governments should give priority to procure those on the list. The list contains eight categories and over 100 energy efficient products. This is the first Chinese government policy measure that uses government procurement to promote energy saving and environment protection [18].

The list has been updated six times during the years 2005, 2006, 2007 and 2009 [19], expanding its scope from the original 8 categories and 10 products to 30 categories and 40 products. The enterprises that participated increased from the original 88 to 266 by the third list. Domestic-produced products have also been added to the list [14].

\subsection{B. Environmental Labeling List}

China's environmental labeling program, established in 1994, has been improved according to the requirement of International Organization for Standardization (ISO) 14020 series standards. China's environmental labeling is consistent with the practice of other countries' Environmental Labeling Programs, such as Japan and Korea, on certification method and procedure. The environment labeling products are certified by certification institution with national certification [14].

In November 2006, the Finance Department and the National Environment Protection Administration announced The Implementation Guidelines for Environmental Symbols Products and the first Government Procurement List for Environmental Symbol Products (or The List). The Guideline stipulates that for any agencies that rely on government budget, either government agencies or service-providing agencies, or associations need to give preference to environmental labeling products and cannot procure products that are harmful to the environment and human health. Environmental symbol products are those that meet not only the quality requirement but also environmental protection in its production, use, and recycling. Compared with products of the same category, environmental labeling products have low level of harm and can conserve resources [20].

The Guidelines and Procurement list establish the green public procurement system by specifying the scope of government green procurement with a list of green products and by establishing working procedures and the specific method and timetable. In order to expand the green procurement scope, and to increase the effectiveness and accuracy of the environment-labeling products, the Finance Department and the National Environment Protection Administration upgraded the lists in March 2007 and August 2008. More green products are added. The number of green products after the revision in $\mathrm{Au}-$ gust 2008 was expanded from 14 categories to 19; the number of enterprises grown from 444 to 760, 71percent; the product models from the originally 2979 to 7159 , a 240 percent increase [20].

In July 2005, the State Council of the Chinese Central People Government issued the State Council about Speeding Up Cycling Economy Guidelines. The Guidelines advocate the consumption behaviors of conserving resources and protecting the environment by using energyefficient, energy-saving products, water-saving products, environment-labeling products, and green symbol food by reducing over-package and disposable products, and requiring governments to engage in green procurement. This document further specifies the direction for public green procurement [21]. The State Council and Environment Protection Administration require the Central Government and provincial governments to implement green procurement in Jan 1, 2007 and a full scale of implementation in all governments to start in Jan. 12008 [22].

\subsection{Initial Implementation}

Implementation of green public procurement program is only in the initial stage. Green procurement regulations 
and practices are implemented in such cities as Guangzhou, Guiying, Shenzhen, Tianjin, Shenyang, Beijing, and Shenzhen. Qingdao was the first city to issue a green procurement list and the first city to actually operate green public procurement in China. Among the many implementation activities were the Green Olympics 2008 Beijing Olympic Games [23]. It is so called because of the implementation of green procurement in acquiring construction materials, in designing the facilities, and in providing services. The Beijing Olympic Committee issued the Olympic Project Environmental Protection Guidelines, the Beijing Olympic Hotel Environment Protection Guideline, the Beijing Olympic Organizing Committee Green Office Guideline and the Olympic Project Building Guidelines. All of these documents played an important role in preventing pollution in designing and using Olympic stadiums.

In order to promote Chinese sustainable consumption and green procurement, the Environmental Development Center of the Environment Protection Administration have undertaken various research, international cooperation such as conferences and established the Chinese Green Purchasing Network (CGPN). It has sponsored several international conferences on green procurement and sustainable procurement. The project-Sustainable Public Procurement in Urban Administrations in Chinawas implemented in Tianjin, Qinhuangdao and Lanzhou to mainstream sustainable public procurement in China. Its first meeting was held in April 2009 [23].

Over past few years, government procurement spending has increased dramatically. As shown in Table 1, the overall government procurement increased 37.1 percent in 2005 over the previous year and 25.7 percent in 2006. Spending on green procurement is increasing, too. With the fastest economic growth, Chinese government procurement power will continue to increase.

\section{Issues with Implementing China's Green Public Procurement}

Whether Chinese government can use its green procurement effectively to protect its environment all depends on how successfully the programs are implemented. The implementation is influenced by the environments in which it takes place. This includes the political environment, economical environment, social environment, the local culture and tradition, and even technical issues involved in the implementation. In this section, we will examine various issues involving China's green public procurement policy implementation.

\subsection{Unfavorable Environments}

China's green public procurement program is facing unfavorable environments for its implementation. First, there is a lack of publicity and media promotion. Edu-
Table 1. Chinese Government Public Procurement Expenditure in 2005 and 2006.

\begin{tabular}{cccccc}
\hline \multirow{2}{*}{ Year } & \multicolumn{3}{c}{$\begin{array}{c}\text { Government Procurements } \\
\text { (in Millions of Yuan) }\end{array}$} & $\begin{array}{c}\text { Annual } \\
\text { Increase }\end{array}$ & $\begin{array}{c}\text { As \% of } \\
\text { GDP }\end{array}$ \\
\cline { 2 - 4 } & All & Provincial \& Local & Central & & \\
\hline 2005 & 292,760 & 251,980 & 40,780 & $37.1 \%$ & $1.6 \%$ \\
2006 & 368,160 & 321,100 & 470,60 & $25.7 \%$ & N/A \\
\hline
\end{tabular}

Sources: [24,25].

cating the public about public issues and policies is an important step in policy implementation. However, in China little effort has been made to promote the importance of green procurement or to inform the public about the content and the goal of public procurement. The government procurement personnel had little knowledge about the environment protection. Together with the use of the lowest bidding selection method, the concept of green procurement is not well established.

The Chinese public does not pay much attention to green procurement. They have no or weak sense of ecosystem and environmental protection. According to a survey, only a quarter of consumers are real green consumers; nearly a third are non-green consumers and nearly half of the consumers are quasi-green procurement. non-green consumption has a big market. Rural residents have an even weaker sense of 'green consumption" than their urban counterparts [26].

In terms of the legal environment, though China has passed laws to set up a green procurement system, it only outlines the general requirements and has not laid out the rules and regulations. For instance, the ninth provision of Government Procurement Method states that government should give priority to high tech products and ecofriendly products, but it does not define eco-friendly products and does not specify the importance of green products.

In terms of market environment, China just started its green procurement production. Compared with developed countries, the structure of green products is not well developed with only a few products currently available. Technological investment is low. This cannot meet the demand for green consumption. China has not set up any program to subsidize green production, and no administrative departments or environmental protection agencies have any strategic plans to promote the green industry. In recent years, some enterprises have used illegal means to sell non-green products as green products. Some enterprises misuse the green product symbols resulting in non-green products being sold as green products. In some places, the government illegally approves certain business to use green product symbols.

In addition, though the Chinese government advocated the production of green products, green products still 
have difficulties entering the market. For example, when applying for green food production, businesses have to go through a complicated procedure and must prove they have large production scale. China has not set any standard to evaluate small and medium-sized organic farms.

\subsection{Problems with Green Public Procurement Program Management}

There are several potential problems with green procurement program management system. First, China does not have a single designated agency that is charged with managing green procurement. Several agencies and ministries are involved in the green procurement management, including the Environment Protection Ministry, the Finance Ministry, the National Development and the Reform Committee as well as the various procurement centers at provincial and local levels. They issue regulations either jointly or on their own, causing policy overlaps, management duplication, and even conflicts among agencies.

The second problem is related to the procurement organization. With the absence of a designated green procurement agency, the green procurement is performed by the procurement centers. These centers do not always apply their own regulations to guide green procurements, and their authority does not align with responsibility.

There is also a lack of communication and coordination among public procurement agencies. Communication involves the exchange of information among public procurement personnel regarding green procurement policies, method, and procedures. Little attention is paid to information about green procurement, and little understanding is present among procurement personnel.

\subsection{Lack of Uniformity in Green Production Definition and Evaluation Criteria}

Any policy design, including green procurement policy, needs to consider the policy contents, the implementation method, and procedures. The key to the successful implementation is the standard that is used to evaluate green products. However, the current green procurement policy lacks the scientific concepts. This is reflected in the following aspects. First, the definitions of green products are not consistent. Different names are given to green products, including environmental labeling products, energy-saving products, and energy-efficient products. Environmental labeling products that are certified by the Chinese Environmental Certification Committee is defined as those that cause no or little harm to environment in its production, use, reuse and that are easy for resource recycling.

Energy-efficient products are defined in The Management Method for Energy Efficient Symbols issued in
August 2004 by the National Development and Reform Committee and the National Quality Technology Monitoring Bureau. The statement stipulates that the refrigerators and air conditioners that are listed in the Production list that have P. R. China's Energy Efficiency labels will be posted with five-degree energy efficiency from September 1, 2005.

The definition of energy-saving product is found in The Government Procurement Implementation Opinion for Energy Saving Products, a joint statement issued by the Finance Ministry and the National Development and Reform Committee in December 2004. An energy-saving product is defined as one that meets the safety and quality requirements of the production category and the efficiency and energy-consumption indicators are the same as those for the advanced international level or as those domestic products that are close to the advanced international level. Enterprises can choose from the two options for this symbol.

As shown in the above discussion, environment labeling products, energy-saving products, and energy-efficiency products share certain commonalities. In some places, they are all referred to as green products. There is no one clear definition of green product. This creates some inconvenience and confusions for both the industry and the government procurement personnel. Industries have to spend more time and energy to meet the different types of labels. Government procurement personnel have to spend more time and energy to learn about variety of green product symbols.

Second, green product evaluation criteria are confusing. The Finance Ministry proposes to adopt a universal standard mandated from the national government. But the Environment Protection Ministry feels this standard is lower than the standard set for the environment labeling products and cannot achieve the environment protection purpose. In addition, there is no national environmental protection standard for such products as Xerox machine, printers, computer or detergents. In summary, China does not have a uniform standard or criteria for green products.

Third, the green product list violates open and fair competition principle. The first list contains only 856 products of 14 categories. This covers only one to two percent of government procurement. Even though the second and third lists expanded the coverage, the list is still too limited compared with the huge scale of public procurement and cannot push the public green procurement process. Moreover, the selection process did not follow fair open competition principle. The products are selected in an inner circle, not through the competitive market basis. Lack of fair and open competition can cause bribery and corruption [27] 


\subsection{Insufficient Resources for Public Green Procurement}

Implementing public green procurement requires both human resource and financial resources and information. However, the current procurement system suffers insufficient funding and inadequate information infrastructure. First, Chinese government has not provided sufficient human resources for public green procurement. The government does not have trained green procurement professionals. Those who involve in green procurement are from the finance department or are management personnel. Many of them do not have procurement experiences and know very little about market analysis, procurement cost control, supplier assessment and management, procurement contract management, negotiation or communication. They had even less understanding and knowledge about green procurement. The members of public procurement evaluation expert committee are from all fields and many occupations. Many of them do not have practical work experience in public procurement. Therefore they tend to use their subjective judgment in deciding the bid. China has not put forward any formal and systematic training to procurement evaluation personnel. Most of the training programs are provided by different agencies, in different jurisdictions in the form of conference. They cannot guarantee the quality and effectiveness. In addition, the ethical standard for public procurement officers is not lifted, and this can leave public procurement exposed to potential corruptions and power struggle.

Second, financial resource for public green procurement is insufficient. Budgeting is important for implementing public procurement programs. Because green product production requires high technology and the process are more complicated than other products, the prices for green products are higher than those for nongreen products. Due to the insufficient budget appropriated to green public procurement, public procurement agencies often adopt the least-cost bidding selection method [28]. According to this method, the price is the most important factor in selecting the bidder given that it meets the material requirement. In this method, the green products are put at a disadvantaged position.

Third, the information infrastructure for green procurement system is lagging behind. Information infrastructure is critical to a successful implementation. It allows public procurement agencies to design the procurement plans, to monitor, and to control the implementation. Implementing public programs is a dynamic process, involving two types of information: policy information and implementing status information. Policy information flows from policy-makers to implementers and clients. It explains policy and programs and how the policy/program will be implemented. The implementation information keeps track of the status of program implementation. In China, there is no one general systematic mechanism to disseminate the green procurement information. The main channel right now is media. As a comparison, developed countries have implemented electronic information system and high effective trading method. The implementation information flows from clients to policy implementers and to the policy makers. At present, China has little knowledge about green procurement implementation. Public procurement personnel need to collect green procurement information such as green product sources and green product rules and laws. Otherwise, procurement officials do not understand the impact of green procurement on the environment.

\subsection{Relying on a Single Method- Administrative Means}

China uses administrative orders and regulations to implement green procurement within specific functions, administrative levels and jurisdictional areas. Administrative method is easy to apply, but lacks legal enforcement power. Government agencies have the options to implement it, or not to implement it, or compromise the implementation. In addition, the implementation lacks legal and economic means. Legal means can standardize and stabilize implementation. Chinese government has not provided subsidies to green product industries.

It is important to see that some GPP implementation issues and obstacles are "universal" in that European Union members and China are all facing them. The most obvious examples are the lack of funding and political support for GPP, and need of training for public procurement professional, and inadequate information infrastructure. At the same time, China's GPP program has its unique implementation problems related to its social, cultural and political environment. As the OECD nations are leading users of GPP, their experiences can provide meaningful guidance to China in various areas.

\section{Policy Recommendations to Improve China's Green Public Procurement System}

Based on the above analysis, the authors believe that the Chinese government needs to make the following changes to address the defects in its green procurement program and implementations.

\subsection{Creating a Favorable Environment}

China needs to address the legal environment under which green public procurement is operated. As stated above, although several laws have been passed, they tend 
to outline the principles, leaving rooms for public procurement agencies not to follow the laws. As a comparison, the developed countries implement their green procurement based on legal basis. For example, Japan 2000 Green Procurement Law stipulates that all the central government agencies must design and implement greenprocurement plan and submit a report to the Secretary of Environment Protection Ministry; local governments should try their best to create the annual green procurement implement plan. In the U.S., federal laws and executive orders are used as the major basis for public procurement. For example, the executive order 13101 requires to "green" government by reducing wastes, recycling resources, and procuring green products [29]. To enhance China's legal environment, from the short-term perspective, Chinese government should issue specific green procurement regulations to require green procurement under the current Government Procurement Law and to standardize and direct or compel government agencies to fulfill their green procurement obligations. From the long-term perspective, China should consider adopting Government Green Procurement Law like many other countries to expressly define green procurement agents and their responsibilities and set green product standards and the green procurement list. In addition, the law should avoid multiple definitions by integrating green products with energy saving products.

Second, China should promote green procurement concept and advocate green consumption among the public. The government should serve as a role model for the citizens by following cyclical economy principle to restrain and standardize its own consumption behaviors and to design its work plan, to undertake public construction, to procure goods and to manage and use recycling products. Green management should be a part of government management and a part of the organizational culture. In addition, government should cultivate green consumption among the public by engaging green campaign and by organizing annual nation-wide energysaving events such as a water-saving week, world environment day, earth day or water day as to foster a keen public awareness of conserving the natural resources and environmental protection [30].

Third, government should improve the green product market. Government should increase the investment in high-technology. Many other countries have produced a substantial number of green products and green industries. For example, in America, green products are 80\% of the new products. One thirds of the new domestic applicants are produced under the "green" banner. Therefore, China has to increase its investment in high-tech. Secondly, China should increase its innovative discretion. China is in the vital stage of technology upgrading. It has to rely on its innovation for this upgrading to increase its competition in the world market and reduce the "green tariff" in the world.

\subsection{Building Green Public Program Organization Capacity}

Chinese government needs to build its organizational capacity to implement its green procurement. First, government should enhance green procurement leadership by establishing a designated national committee and leading organization with diverse representation from green product experts, green product makers, relevant government officials and even consumers and civic group members. This leading organization would coordinate and carry out the relevant green procurement policy, specify the tasks for each department, build government green procurement tracking and report system, evaluate the implementation, issue green procurement guiding principle, draft procurement guiding outline, make environment information handbook and to promote green procurement activities.

China should clarify the approach for its green procurement implementation. There are two different approaches to promote green procurement. One is the topdown approach as implemented in France where the central government makes procurement plan that is executed by the lower level of government. The alternative is the bottom up approach used in Swiss where local civic organizations take the lead while government only provides assistance. In China, the top down model is more appropriate. The Government Procurement Law expressly states that public procurement should be centralized. The top down approach also fits China's setting better.

Third, Chinese government should promote the interaction between environment protection agencies and procurement agencies. China has upgraded its Environment Protection Administration into the Environment Protection Ministry in 2008 [31]. As a way to implement its mission of protecting environment, the Environment Protection Ministry should get involved in designing and publishing various guiding documents and handbooks and establishing various service centers to provide green procurement information to public procurement personnel. At the same time public procurement agencies should communicate with environment protection agencies.

\subsection{Setting Appropriate Green Procurement Standards and Criteria}

Environment labeling products are the foundation for green public procurement in many countries. China should speed up the construction of the environment la- 
beling production certification system and should expand the procurement list. The list should have a wide coverage of products, reflecting the actual need. The process should be fair and rational in order to avoid distortionary behaviors and corruptions. Second, the list must be upgraded constantly. The list should be a dynamic one. That is, the list should be expanded, adding new products that are needed to the list and removing those products whose production technology fails to reach the environment standard and whose certification period expires. In addition, China should consider a "green standard". Instead of directly producing the procurement list, the relevant government standard management agencies set explicit procurement standard for materials for engines, electronic, IT products, construction, architecture and interior design from energy-saving, energy-efficiency and environmental-friendly products. Such a green standard will eliminate distortionary behaviors from producers and corruption that might occur in making procurement list. The disadvantage is that the procurement personnel cannot tell which product is green, and this makes it less operational [32].

\subsection{Increasing Human Resources for Public Green Procurement}

As China expands the scope for government procurement and as the system is getting improved, it will need a large number of procurement personnel and supply agents. It is imperative to have an effective green procurement personnel management strategy and to set up training centers for green procurement personnel. The training should focus on general skills, communication skills, product knowledge, thinking and analysis skills. In many countries, universities and research institutes provide procurement courses as a part of the degree curriculum [33]. Chinese higher education institutions should consider offering public procurement programs or joint procurement programs with government.

Second, we need to speed up professional certification system. In Britain, government procurement officer association proposed training for procurement personnel in 1931. British Public Procurement Research Institute was established in 1949 to facilitate certifying process. Canada established a training and certification program for the procurement personnel nationwide [33]. China should establish a professional certification system as soon as possible to speed up management skills, practical skills, and personnel quality.

\subsection{Building Green Public Procurement Information Infrastructure}

Environment information is essential for green public policy making and for issuing procurement list. In Japan, its government pays great attention to standardizing, obtaining and disseminating environment-protection information. China should set up the product environment information standard, announce the actual implementation of green public procurement, create supervising mechanism for the People's Congress and for the public over green public procurement implementation. China should provide an information platform where procurement personnel and the suppliers can obtain green procurement information and the most up-to-day green product information and technology information and where green product list and green procuring agency names are announced at certain intervals.

\subsection{Facilitating Green Procurement with Subsides and Tax Policies}

As the production cost for green products is higher than non-green products, the Chinese government should also consider providing subsidies to allow procurement to procure green products at a higher than the market price. Many countries adopt this policy and it has proven successful [34]. In addition, government should also provide subsidies to green product enterprises and developers to help them to cover their production cost and to encourage more businesses to engage in green product industry.

In addition to subsides, the government can use tax policy to influence the green consumption by providing tax breaks to encourage green production and green consumption and by levying higher taxes (e.g., higher value-added tax and resource excise) on those products that cause pollution and over-consumption.

\section{Conclusions}

With its huge and ever-increasing procurement power, the Chinese government has the capability to protect the environment through its green procurement programs. Though relatively late in adopting public procurement systems, China has created green public procurement policies through a series of legislations and administrative regulations and has started to implement them. The focus of this paper is to examine the issues involved in its implementation and make suggestions as to how to make green public procurement program more effective.

Implementing China's green procurement program will be a gigantic task for the Chinese government. It needs to address a series of issues and need to watch and study its policy and the implementation constantly. Indeed, implementation of green public procurement also opens tremendous opportunities for research, both theoretical and empirical. How should be policy be finetuned? How should the structure be modified? What are some good practices for effective green public procurement? How does the organizational structure affect its 
implementation? How costly is the green procurement? How effective is the green procurement on the environment? As little research has been conducted about green public procurement, the authors would like to invite more researchers to study this rich area so as to provide more insight about how to improve China's green procurement programs.

\section{REFERENCES}

[1] C. McCrudden, "Buying Social Justice: Equality, Government Procurement, and Legal Change,” Oxford University Press, New York, 2007.

[2] United Nations Office for Project Services (UNOPS), "2008 Annual Statistical Report on United Nations Procurement: Sustainable Procurement Supplement,” 2009. http://www.ungm.org/Publications/Documents/ASR_200 8_SP_supplement.pdf

[3] European Commission, "International Policy Framework."

http://ec.europa.eu/environment/gpp/international_policy _framework_en.htm.

[4] M. Hidson and S. Clement, "Driving Sustainability through Procurement: The Procura + Campaign,” 3rd International Public Procurement Conference Proceedings, Amsterdam, 28-30 August 2008.

[5] K. Parikka-Alhola, A. Nissinen and A. Ekroos, "Green Award Criteria in the Most Economically Advantageous Tender in Public Purchasing,” In: K. V. Thai and G. Piga, Eds., Advancing Public Procurement, PrAcademics Press, Boca Raton, 2006, pp. 257-279.

[6] L. Carlsson and F. Waara, "Environmental Concerns in Swedish Local Government Procurement,” In: K. V. Thai and G. Piga, Eds., Advancing Public Procurement, PrAcademics Press, Boca Raton, 2006. http://www.ippa.ws/IPPC2/BOOK/Chapter_11.pdf

[7] D. Marron, "Greener Public Purchasing as an Environmental Policy Instrument,” OECD Journal on Budgeting, Vol. 3, No. 4, 2003, pp.71-102. doi:10.1787/budget-v3-art23-en

[8] A. Ochoa and C. Erdmenger, "Study Contract to Survey the State of Play of Green Procurement in the EU-Final Report,” International Council for Local Environment Initiatives, 2003. http://www.iclei-europe.org/index.php?id=gppsirvey

[9] P. Kippo-Edlund, H. Hatua-Heikkila, H. Miettinen and A. Nisssinen, "Measuring the Environmental Soundness of Public Procurement in Nordic Countries,” Noric Council of Ministers, Copenhagan, 2005. http://www.norden.org/pub/miljo/miljo/sk/TN2005505

[10] M. Bouwer, K. de Jong, M. Jonk, T. Berman, R. Bersani, H. Lusser A. Nissinen, K. Parikka, K and P. Szuppinger, "Green Public Procurement in Europe 2005-State Overview,” Virage Milieu \& Management, Harleem, 2005. http://ec.europa.eu/environment/gpp/pdf/report_facts.pdf

[11] P. Szuppinger and C. Viganò, "Green Public Procurement in Europe 2006-Conclusions and Recommendations.
Virage Milieu \& Management,” 2006.

http://europa.eu.int/comm/environment/gpp

[12] E. C. L. Prenen, "Green and Sustainable Public Procurement in the Netherlands: An Inconvenient Truth," 3rd International Public Procurement Proceedings, 2008. http//www.ccgp.gov.cn.cgtt/241908.shtml

[13] P. A. Gunther "Hurdles in Green Purchasing-Method, Findings and Discussion of the Hurdle Analysis,” In: C. Erdmenger, Ed., Buying into the Environment: Experiences, Opportunities and Potential for Eco-Procurement, Greenleaf Publishing, Sheffield, 2003, pp. 30-50.

[14] M. Ju, L. Zhang, L. Zhan, H. Ren and Z. Yang, "Public Green Procurement in China: Development Course, Program Management and Technical Methods, Sustainable Public Procurement in Urban Administration in China: An Action under Europe Aid's SWITCH-Asian Program Paper,” No. 02-EN/CH, 2009.

www.public-procurement.cn/English\%20Docment/Repor ts\%201/Public\%20Green\%20Procurement\%20in\%20Chi na.pdf

[15] Standing Committee of the National People's Congress of the People's Republic of China, "Law of the People's Republic of China on the Promotion of the Clean Production,” 29 June 2002.

http://english.mep.gov.cn/Policies_Regulations/laws/envi r_elatedlaws/200710/t20071009_109966.htm

[16] Standing Committee of the National People's Congress (NPC) of the People's Republic of China, "The Government Procurement Law of the People's Republic of China”, 29 June 2002.

http://www.gov.cn/english/laws/2005-10/08/content_750 23.htm

[17] Standing Committee of the 11th National People's Congress (NPC) of the People's Republic of China, "Circular Economy Law of the People's Republic of China,” 29 August 2008.

http://www.chinaenvironmentallaw.com/wp-content/uplo ads/2008/09/circular-economy-law-cn-en-final.pdf

[18] Finance Ministry of the People's Republic of China, "Implementation Guidelines for Government Procurement of Energy-Saving Products,” 2004.

http://www.caigou2003.com/law/cfagui/200505/2005051 2174126_217027.html

[19] Finance Ministry of People's Republic of China and the National Development and Reform Committee, "Finance Ministry and the National Development and Reform Committee regarding Adjustment of Energy Saving Product Government Procurement List Notice,” 2009. http://www.ccgp.gov.cn/zcfg/gjfg/gjfg/976372.shtml

[20] "The Third Green Procurement List Has Been Formerly Issued," China Finance and Economy: 4, August 6, 2008.

[21] State Council, "The State of Council Opinions on Regarding Speeding Up Cyclical Economy,” 2 July 2005. http://www.gov.cn/zwgk/2005-09/08/content_30305.html

[22] China Government Procurement Network, “Our Country Will Gradually Implement Government Procurement Policy,” 7 May 2008. http://www.cgpn.org/NewsDetails.aspx?id=296 
[23] M. Ju, L. Zhang, L. Zhan, H.Ren and Z. Yang, "Practical Insights and Illustrative Examples on Sustainable Public Procurement: Cases Studies from China, Sustainable Public Procurement in Urban Administration in China: An Action under Europe Aid's SWITCH-Asian Program Paper,” No. 04-EN/CH, 2009.

http://www.public-procurement.cn/English\%20Document /Presetions\%20of\%20Kik-off\%20meeting/China\%20case \%20studies.pdf

[24] X. Q. Guo, "2006 Government Procurement Reaches 368,160 Million Yuan (R/OL),” 2007. http://www.ccgp.gov.cn.cgtt/241908.htm

[25] Chinese Ministry of Finance, "2006 Government Procurement Year Book,” 2006.

http://www.mof.gov.cn/mof/zaixianfuwu/baokannianjian/ CaiZhengBuBaoKanNianJian/CaiZhengBuNianJian/Cai ZhengBuZhengFuCaiGouNianJian

[26] MBA Wisdom Encyclopedia, “Green Consumption,” 2011. http://wiki.mbalib.com

[27] "China Green Procurement May Be a Double-Edged Sword," China Youth Paper, 24 November 2006. http://yesky.n169.com
[28] “What Is the Lowest Bidding Method?” 1 March 2009. http://www.caigou2003.com/gpnews/yaowen/200903/200 90301161058_272414.htm

[29] White House, "Greening the Government through Waste Prevention, Recycling, and Federal Acquisition,” 14 September 1998.

http://ceq.hss.doe.gov/nepa/regs/eos/eo13101.htm

[30] A.-G. Hu, “China: New View for Development,” ZheJiang People’s Publisher, Hangzhou, 2004.

[31] “How Can 'Big Department System’ Become Big?” 20 March 2008. http://www.chinareviewnews.com

[32] H. Xu, "Government Procurement Role in Environment Protection and Energy Saving: Functions and Methods," Journal of Environmental Protection, Vol. 23, No. 8, 2005, pp. 65-68.

[33] F. Cao, “The Appropriate Use of Government Procurement Bidding," Enterprise Management Publisher, Beijing, 2002.

[34] S. Zuo, “A Brief Discussion of Government Green Procurement,” Journal of Commerce Perspective, Vol. 34, No. 10, 2006, pp. 165-167. 